\section{Developmental Changes in Tissue Thyroid Hormone Levels of Red Sea Bream Pagrus major}

Short Paper

\author{
Ryo Kimura, ${ }^{* 1}$ Masatomo Tagawa, ${ }^{* 2}$ \\ Masaru Tanaka, ${ }^{* 3}$ and Tetsuya Hirano*2 \\ (Received September 17, 1991)
}

Red sea bream Pagrus major together with black sea bream Acanthopagrus schlegeli are the most common sparid species in temperate coastal waters around Japan. Larvae of both species co-occur seasonally and spatially, although the early juveniles occupy different nursery areas. ${ }^{\text {t) }}$ In laboratory-reared black sea bream, the wholebody thyroxine $\left(T_{4}\right)$ concentration increased coinciding with inshore migration of the larvae in nature. ${ }^{2)}$ Larvae of red sea bream undergo similar morphological changes to those of black sea bream, but migrate to near the shore at different developmental stage. In order to examine the involvement of thyroid hormones in morphogenic and behavioral events, developmental changes in thyroid hormone levels of red sea bream larvae were examined, and discussed in comparison with those of black sea bream.

Fertilized eggs of red sea bream were obtained from a parental stock in Fukui Prefectural Farming Fisheries Center, and transported to the Fisheries Research Station of Kyoto University on June 9, 1988. Larvae and Juveniles were reared under natural water temperature $\left(19.2-24.0^{\circ} \mathrm{C}\right)$ and photoperiod, and fed with rotifers and brine shrimp nauplii as previously described. ${ }^{3)}$ Three pooled samples (about $50 \mathrm{mg}$ in wet body weight) were collected from the dominant developmenta! stage (according to Fukuhara's classification for black sea bream ${ }^{4}$ ) at 2-5 day intervals until

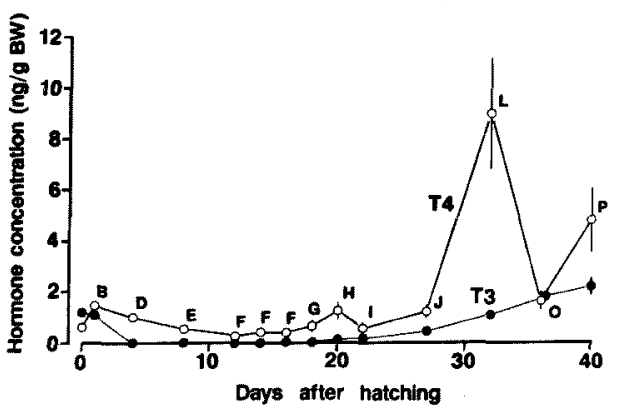

Fig. 1. Changes in $T_{4}(O)$ and $T_{3}(\bullet)$ concentrations and developmental stages of red sea bream. Each point represents mean and standard errors $(\mathrm{n}=3$, except for $1,4,8$ days). Letters indicate the developmental stage of the sample.
40 days after hatching (day 40), except for day 1, 4 and 8 when one pooled sample (containing more than 400 individuals) was used. These samples were frozen at $-30^{\circ} \mathrm{C}$, and $T_{4}$ and triodothyronine $\left(T_{3}\right)$ were extracted and assayed as described by Tagawa and Hirano.")

As shown in Fig. 1, $T_{4}$ and $T_{3}$ concentrations in fertilized eggs were $0.61 \mathrm{ng} / \mathrm{g}$ and $1.17 \mathrm{ng} / \mathrm{g}$, respectively. $T_{4}$ concentrations were less than $1.3 \mathrm{ng} / \mathrm{g}$ until day 27 (J stage), increased markedly but temporarily to $9.0 \mathrm{ng} / \mathrm{g}$ on day 32 (L stage, SL $11.1 \mathrm{~mm}$ ), and then decreased to less than half of the peak level on day 36 (O stage). On the other hand, $\mathrm{T}_{3}$ concentrations were non-detectable (less than $0.1 \mathrm{ng} / \mathrm{g}$ ) until day 18 , became detectable on day 20 ( $\mathrm{H}$ stage), and reached $2.2 \mathrm{ng} / \mathrm{g}$ on day 40 (P stage).

The red sea bream larvae complete morphological transformation to juvenile (metamorphosis) at $\mathrm{L}$ stage (day 32), when a significant increase in $T_{4}$ concentration and gradual increase in $T_{3}$ concentration were observed. Involvement of thyroid hormones in flounder metamorphosis is well established. ${ }^{\theta}$. Increases in thyroid hormone concentrations have also been observed during metamorphosis in a number of teleost fishes including black sea bream. ${ }^{7}$ ) ${ }^{2}$ Thus, the $T_{4}$ surge in red sea bream larvae seems to be related to morphological transformation.

In red sea bream, the L stage also coincides closely with their habitat shift from pelagic to demersal life. ${ }^{3}$ ) On the other hand, black sea bream larvae undergo inshore migration at I stage, when a marked $T_{4}$ surge was observed. ${ }^{2}$ Therefore, the fact that the $T_{4}$ concentration did not increase at I stage in red sea bream, when they undergo similar morphological changes to black sea bream, suggests that $T_{4}$ surge at I stage in black sea bream is related to inshore migration at that stage. Thus, the $T_{4}$ surge at the $L$ stage in red sea bream is likely to be related to the migration as well as the morphological transformation.

We would like to thank Mr. H. Ooe, Fukui Prefectural Farming Fisheries Center, for kindly providing the eggs. This study was supported in part by funds from the Cooperative Program (No. 88130) provided by Ocean Research Institute, University of Tokyo, to M. T, and also from the Ministry of Agriculture, Forestry, and Fisheries (BMP 91-II-2-1) to T. Hirano and M. Tanaka.

\section{References}

1) 1. Kinoshita and M. Tanaka: Nippon Suisan Gakkaishi, 54 $1807-1813(1990)$.

2) M. Tanaka, R. Kimura, M. Tagawa, and T. Hirano: Nippon Suisan Gakkaishi, 57, 1827-1832 (1991).

3) R. Kimura and M. Tanaka: Nippon Suisan Gakkaishi, 57, 1833-1837 (1991).

4) O. Fukuhara: Nippon Suisan Gakkaishi, 53, 371-379 (1987).

5) M. Tagawa and T. Hirano: Gen. Comp. Endocrinol, 76, $437-443(1989)$.

6) Y. Inui and S. Miwa: Gen, Comp. Endocrinol, 60, 450-454 (1985).

7) M. Tanaka, M. Tagawa, S. Matsumoto, and T. Hirano: Aquaculture, (in submitted).

8) M. Tanaka: Trans. Am. Fish. Soc., 114, $471-477$ (1985).

*1 National Research Institute of Fisheries Science, Kachidoki, Chuo, Tokyo 104, Japan (木村 量：水䳸 宁中央水鷹研究所).

*2 Ocean Research Institute, University of Tokyo, Nakano, Tokyo 164, Japan (田川正朋, 平野暂也：東宗 大学海洋研究所).

*3 Department of Fisheries, Faculty of Agriculture, Kyoto University, Kyoto 606, Japan (田中 克: 京都 大学農学部水産学科). 